\title{
PENGARUH QUALITY OF WORK LIFE (QWL) TERHADAP KINERJA PEGAWAI DENGAN DISIPLIN DAN KEPUASAN KERJA SEBAGAI VARIABEL INTERVENING
}

\author{
Titik Nurbiyati \\ Fakultas Ekonomi Universitas Islam Indonesia \\ e-mail: titiknurbiyati@yahoo.co.id
}

\begin{abstract}
The research is aimed to measure the influence of Quality of Work Life (QWL) on employee performance while discipline and work satisfaction are the intervening variables. The data are primary ones that are analyzed with regression and path analysis. The data analysis shows that QWL significantly influenced on work analysis and workers' performance but did not influence on work discipline. Simultaneously QWL, work discipline and work satisfaction as a whole significantly influenced on workers' performance. There is an indirect influence ( $Q W L$ on the performance through work discipline) that is smaller than the direct influence. There is an indirect influence ( $Q W L$ on the performance through work satisfaction) that bigger than the direct influence $(Q W L$ on the performance). $R$ Square score 0.553 means that $Q W L$, work satisfaction and work discipline influenced on the performance by $55.30 \%$ while the performance was influenced by other variables by 44.7\%. Based on the results above for QWL of growth and development category the researcher recommends Training Need Analysis (TNA) to fulfill the need of employee that are in accordance with the needed work. For QWL of compensation category it needs salary survey of sampled universities to compare the data of policy and salary methods. It needs further researches to measure the influence of other variables besides $Q W L$, work discipline and work satisfaction on the performance.
\end{abstract}

Keywords: Quality of Work Life (QWL), work discipline, work satisfaction, performance

\begin{abstract}
Abstrak
Penelitian ini dimaksudkan untuk mengetahui pengaruh antara variable Quality of Work Life (QWL) terhadap kinerja karyawan dengan disiplin dan kepuasan kerja sebagai variabel intervening. Data dalam riset ini menggunakan data primer dengan menggunakan alat analisis regresi dan analisis path. Dari analisis data diperoleh hasil secara parsial QWL berpengaruh signifikan terhadap kepuasan kerja dan kinerja pegawai namun tidak berpengaruh terhadap disiplin kerja. Seara simultan QWL, disiplin kerja dan kepuasan kerja secara bersama-sama berpengaruh signifikan terhadap kinerja pegawai. Selain itu ada pengaruh tidak langsung (QWL terhadap kinerja melalui disiplin kerja ) lebih kecil dibandingkan pengaruh langsung terhadap kinerja. Kemudian ada pengaruh tidak langsung (QWL terhadap kinerja melalui kepuasan kerja) lebih besar dibandingkan pengaruh langsung (QWL terhadap kinerja). Nilai R Square sebesar 0,553 yang artinya variabel QWL, kepuasan kerja dan disiplin kerja mempengaruhi kinerja hanya sebesar 55,30 \% sedangkan 44,7\% dipengaruhi faktor lain. Rekomendasi dari hasil riset ini variabel QWL kategori pertumbuhan dan perkembangan perlu adanya program Training Need Analysis (TNA) guna memenuhi kebutuhan tenaga kependidikan yang sesuai dengan kebutuhan pekerjaan. Sedangkan variabel QWL kategori kompensasi perlu mengadakan salary survey terhadap perguruan tinggi yang dipilih secara sampling yang bertujuan untuk melakukan perbandingan data mengenai kebijakan, praktek dan metode penggajian. Perlu dilakukan riset lanjutan untuk mengetahui faktor yang berpengaruh terhadap kinerja selain faktor QWL, disiplin kerja dan kepuasan kerja.
\end{abstract}

Kata Kunci: Quality of Work Life ( $Q W L)$, Disiplin Kerja, Kepuasan kerja dan Kinerja Karyawan 


\section{PENDAHULUAN}

Persaingan yang sangat ketat dalam dunia bisnis menuntut organisasi bekerja lebih cerdas. Berbagai cara dilakukan organisasi untuk menciptakan keunggulan bersaing. Salah satu aspek terpenting dalam menciptakan keunggulan bersaing adalah dengan meningkatkan kualitas sumber daya manusia yang dimiliki (Husnawati, 2006). Masalah pokok dalam manajemen sumber daya manusia adalah bagaimana membangun budaya produktif dalam perusahaan sehingga akan meningkatkan kinerja organisasi (Hasibuan (2012). Kinerja sebagai penentu tingkat daya saing baik pada level individu, perusahaan, industri maupun negara (Sumbodo, 2010). Dalam upaya meningkatkan kualitas kehidupan kerja atau Quality of Work Life (QWL) tidaklah mudah karena dalam prosesnya banyak sekali tantangan bahkan jika tidak didukung oleh berbagai pihak biasanya usaha ini bisa terjadi kegagalan. Dukungan manajer sangat dibutuhkan dan penting karena akan menentukan kinerja para pegawai. Perlu diketahui bahwa kinerja pegawai secara individu sangat dipengaruhi oleh QWL dengan kata lain memiliki hubungan signifikan (Bhe \& Che Rose 2007). Hal ini didukung oleh hasil riset Lau \& May (1998) yang menunjk kan bahwa kuatnya hubungan antar Quality of work life (QWL) dengan kinerja organisasi.

Kinerja karyawan akan mempengaruhi seberapa banyak mereka memberi kontribusi kepada organisasi ( Mathis \& Jackson, 2006). Tingginya tingkat kinerja dapat ditingkatkan melalui peningkatan kualitas dan kuantitas kerja. Upaya yang dilakukan untuk meningkatkan kinerja serta meningkatkan kualitas output salah satunya melalui partisipasi serta keterlibatan karyawan dalam proses pengambilan keputusan dan untuk memenuhi kebutuhan para karyawan dengan penerapan Qualityof Work Life (QWL) (Siagian, 2009). Untuk membantu menyeimbangkan pekerjaan dengan kebutuhan, minat dan tekanan yang dihadapi oleh karyawan sehingga bermanfaat untuk meningkatkan kinerja perusahaan dan mengurangi turnover karyawan dengan cara mengembangkan QWL (Pramdhana, 2013). Pimpinan harus memiliki banyak solusi untuk menjawab tantangan-tantangan manajemen dengan menciptakan QWL yang sesuai agar para karyawan yang bekerja dapat meraih kepuasan dalam bekerja, serta disiplin kerja yang tinggi terhadap organisasi.

QWL mencakup aktifitas-aktifitas yang ada di dalam perusahaan, yang diarahkan untuk meningkatkan suatu kondisi kehidupan kerja yang dapat membangkitkan semangat kerja dalam melaksanakan tugas mencapai sasaran perusahaan (Cascio, 2006). Perusahaan perlu menumbuhkan dan membina semangat kerja karyawan secara terus-menerus agar karyawan menjadi terbiasa dan mempunyai semangat kerja yang tinggi sehingga berdampak pada kinerja karyawan. Perilaku karyawan yang hanya ingin memenuhi kebutuhan dan keinginan diri sendiri akan berdampak pada berkurangnya rasa kepuasan anggota lainnya sehingga akan timbul konflik internal dalam kelompok yang akan mempengaruhi kinerja perusahaan.

QWL merupakan permasalahan utama yang patut mendapat perhatian oleh organisasi (Lewis dkk, 2001). Pernyataan tersebut menunjk kan bahwa QWL dipandang mampu meningkatkan peran serta sumbangan antar anggota karyawan terhadap organisasi. Oleh karena itu sangat diperlukan perhatian yang serius oleh para pimpinan organisasi dalam mewujudkan QWL, karena hal tersebut akan menolong organisasi dalam mempertahankan karyawan-karyawan terbaik mereka serta dapat meningkatkan kinerja organisasi. Selain QWL, disiplin benar-benar memainkan peran penting dalam membentuk tingkah laku. Seperti halnya penghargaan yang efektif dalam memotivasi orang, disiplin jika digunakan secara tepat maka dapat meningkatkan kinerja. Disiplin harus dilaksanakan secara adil dan konsisten (Hasibuan, 2012). Tindakan disiplin yang efektif akan mendorong individu untuk meningkatkan kinerja yang menguntungkan individu tersebut dan tentunya juga organisasi.

Dari latarbelakang tersebut diatas maka QWL, kepuasan kerja, disiplin kerja dan kinerja organisasi yang menjadi bahan pokok penelitian pada organisasi yang bergerak pada bidang pendidikan yakni Fakultas Ekonomi Universitas Islam Indonesia Yogyakarta. Penelitian ini dibatasi hanya untuk tenaga kependidikan, harapan dari hasil riset menjadi bahan pertimbangan manajemen untuk menciptakan QWL, karyawan puas terhadap QWL akan berdampak terhadap disiplin dalam bekerja sehingga bisa meningkatkan kinerja organisasi. Secara spesifik studi ini bertujuan untuk meneliti 
tentang pengaruh QWL, disiplin kerja dan kepuasan kerja terhadap kinerja secara parsial maupun simultan, pengaruh QWL terhadap disiplin kerja, pengaruh QWL terhadap kepuasan kerja, dan menganalisis pengaruh secara langsung (QWL terhadap kinerja) dengan pengaruh tidak langsung (QWL terhadap kinerja melalui disiplin) pada pegawai dan pengaruh secara langsung (QWL terhadap kinerja) dengan pengaruh tidak langsung (QWL terhadap kinerja melalui kepuasan kerja) pada pegawai.

\section{TINJAUAN PUSTAKA}

Di dalam bagian ini akan dibahas tentang variabel-variabel yang membentuk model penelitian yang didasarkan dari teori maupun hasil riset pendahulu.

\section{Quality of Work Life (QWL)}

QWL mempunyai peran kunci untuk meningkatkan kinerja bagi sebagian organisasi. (Mousavi dkk, 2011). Dengan menerapkan QWL yang baik membuat karyawan lebih sehat, lebih berkomitmen, lebih aman dalam bekerja dan memproduksi lebih banyak barang, serta akan mengurangi pengeluaran organisasi (Horst dkk, 2014). Pendekatan ini memotivasi orang dengan tidak hanya memenuhi kebutuhan ekonomi, tetapi juga memenuhi kebutuhan sosial dan psikologis mereka (Balaji, 2013). QWL mengacu pada tingkat kebahagiaan atau ketidakpuasan seseorang terhadap karirnya. Mereka yang menikmati kariernya dikatakan memiliki QWL yang tinggi, sementara mereka yang tidak bahagia atau yang kebutuhannya tidak terpenuhi dikatakan memiliki QWL yang rendah. QWL dipandang sebagai alternatif pengendalian dalam mengelola karyawan serta merupakan metode terbaik untuk mempertahankan karyawan yang berbakat sehingga memperoleh kinerja yang lebih baik. Unsur QWL memperhatikan dampak bekerja pada individu dalam membandingkan efektivitas organisasi dan juga ide partisipasi dalam memecahkan masalah dan keputusan organisasi (Taleghani dkk, 2014).

Manajemen kinerja didasarkan kepada kesepakatan tentang sasaran, persyaratan pengetahuan, keahlian, kompetensi, rencana kerja dan pengembangan. Dengan demikian manajemen kinerja mancakup pengkajian ulang terhadap kinerja secara berkesinambungan dan dilakukan secara bersama berdasarkan kesepakatan mengenai sasaran persyaratan pengetahuan, keahlian profesi, rencana kerja, dan pengembangan serta implementasi rencana peningkatan dan pengembangan lebih lanjut. Secara kinerja ditunjukan untuk meningkatkan aspek-aspek kinerja yang meliputi sasaran yang dicapai, kompetensi dan efektifitas kerja (Dharma, 2012). Cascio (2006) QWL merupakan salah satu tujuan penting dalam memenuhi kebutuhan dan keinginan pegawai. Kinerja dipengaruhi oleh beberapa variabel salah satunya quality of work life.

Berdasarkan hubungan antara kedua variabel tersebut, maka diajukan hipotesis:

H1: Terdapat pengaruh positif dan siginifikan antara variabel QWL terhadap kinerja.

$\mathrm{H} 3$ : terdapat pengaruh positif dan signifikan antara QWL terhadap kepuasan kerja.

H8: terdapat pengaruh tidak langsung QWL terhadap kinerja melalui variabel kepuasan kerja.

\section{Disiplin Kerja}

Kedisiplinan merupakan fungsi operatif manajemen sumber daya manusia yang terpenting karena semakin baik disiplin karyawan, semakin tinggi prestasi kerja yang dapat dicapainya (Hasibuan, 2012). Disiplin merupakan tindakan atau perilaku manajemen yang menuntut pemenuhan kebutuhan akan standar organisasi (William B. Wherter dan Keith Davis, 1996). Disiplin benarbenar memainkan peran penting dalam membentuk tingkah laku (Buhler, 2007). Disiplin harus dilaksanakan secara adil dan konsisten. Setiap karyawan yang terlibat dalam tingkah laku yang tidak tepat harus diperlakukan sama. Disiplin progresif memberikan disiplin yang secara progresif lebih keras untuk contoh-contoh tingkah laku tidak tepat yang diulangi. Program ini akan dimulai dengan memberikan peringatan lisan pada saat pelanggaran pertama kali dilakukan. Disiplin kerja dipengaruhi oleh salah satu variabel yang akan diteliti yaitu QWL. Penelitian Nuryati (2010) menyimpulkan bahwa QWL mempunyai pengaruh signifikan terhadap produktivitas karyawan. Disiplin kerja berpengaruh signifikan terhadap kinerja karyawan (Febiningtyas dan Ekaningtias, 2014) Kinerja dapat dicapai organisasi apabila karyawan dapat lebih disiplin (Dunggio, 2013). Karena itu hipotesis yang diajukan dalam penelitian ini adalah: 
H2 : terdapat pengaruh signifikan antar QWL dan disiplin kerja.

H4 : Terdapat pengaruh positif dan signifikan antar variabel disiplin kerja terhadap kinerja karyawan.

H7 : terdapat pengaruh tidak langsung antar QWL terhadap kinerja melalui variabel disiplin kerja.

\section{Kepuasan Kerja}

Evaluasi yang menggambarkan seseorang atas perasaan sikap senang atau tidak senang, puas atau tidak puas dalam bekerja dapat disebut dengan kepuasan kerja (Rivai dan Sagala, 2009). Kepuasan kerja dapat ditunjukkan dengan adanya respon afektif atau emosional terhadap berbagai aspek pekerjaan seseorang (Pushpakumari, 2008). Jika seseorang mempunyai tingkat kepuasan kerja tinggi maka akan memiliki sikap positif terhadap pekerjaannya, akan tetapi sebaliknya apabila tidak puas dengan pekerjaannya akan berdampak pada sikap negatif terhadap pekerjaan. Kepuasan kerja juga mencerminkan sikap positif karyawan terhadap pekerjaannya. Ada alasan mengapa perusahaan harus benar-benar memperhatikan kepuasan kerja antara lain manusia berhak diberlakukan dengan adil dan hormat, kepuasan kerja dapat menciptakan perilaku yang mempengaruhi fungsi- fungsi yang ada dalam perusahaan. Penerapan QWL akan mempengaruhi kepuasan kerja diperusahaan (Daud: 2010). Sedangkan dari penelitian yang dilakukan Setiawan (2006) mengatakan bahwa disiplin kerja dan motivasi berpengaruh terhadap kinerja karyawan baik secara simultan maupun parsial. Berdasarkan hal diatas maka dapat dihasilkan hipotesis sebagai berikut;

H5 : Terdapat pengaruh positif dan signifikan antar variabel kepuasan kerja terhadap kinerja karyawan

H6 : Terdapat pengaruh positif dan signifikan antar QWL, disiplin kerja dan kepuasan kerja terhadap kinerja karyawan

\section{METODE PENELITIAN}

Penelitian ini dilaksanakan di Fakultas Ekonomi, Universitas Islam Indonesia Yogyakarta. Dalam penelitian ini menggunakan pendekatan kuantitatif dengan menggunakan variabel independent dan variable dependen serta variabel intervening. Adapun variable independent dalam penelitian ini yakni Quality of Work Life. Disiplin kerja dan kepuasan kerja sebagai variabel intervening sedangkan variable dependentnya adalah kinerja karyawan. Data yang diperlukan dalam penelitian ini adalah data primer yaitu data yang diperoleh secara langsung dari sumbernya. Data primer yang dimaksud adalah keterangan langsung dari responden dengan menjawab kuisioner. Kuisioner ini disebarkan langsung pada pegawai tenaga kependidikan Fakultas Ekonomi UII. Instrumen penelitian (kuisioner) yang baik harus memenuhi persyaratan yaitu valid dan reliabel. Untuk mengetahui validitas dan reliabilitas kuesioner perlu dilakukan pengujian atas kuisioner dengan menggunakan uji validitas dan uji reliabilitas.

Populasi menurut Sugiyono (2012) adalah wilayah generalisasi yang terdiri atas subyek yang mempunyai kualitas dan karakteristik tertentu yang ditetapkan oleh peneliti untuk dipelajari dan kemudian ditarik kesimpulannyaPopulasi dalam penelitian ini adalah seluruh pegawai tenaga kependidikan Fakultas Ekonomi UII. Dalam penelitian ini jumlah populasi 107. Karena jumlah populasi relatif sedikit maka dalam penelitian ini penentuan responden menggunakan sensus. Sensus artinya jumlah populasi dijadikan responden semuanya. Setelah dilakukan penelitian mengenai pengaruh dari variabel QWL terhadap kinerja dengan disiplin kerja serta kepuasan kerja sebagai variabel intervening pada tenaga kependidikan Fakultas Ekonomi UII, maka dapat dilakukan perhitungan dan analisis. Data yang digunakan merupakan data primer hasil kuesioner yang disebarkan kepada tenaga kependidikan. Kuesioner perlu diuji dengan menggunakan uji validitas dan uji reliabilitas. Metode analisis data yang digunakan dalam penelitian ini meliputi analisis regresi dan path analysis.

Pengujian regresi linier berganda dapat dilakukan setelah model dari penelitian memenuhi syarat-syarat yaitu lolos dari asumsi klasik. Syarat-syarat yang harus di penuhi adalah data tersebut harus terdistribusikan secara normal, tidak mengandung multikoloniaritas, dan heterokidastisitas (Ghozali, Imam, 2006).

\section{ANALISIS DATA DAN PEMBAHASAN}

Pada Analisis data dan pembahasan menjelaskan hasil penelitian mengenai pengaruh dari variabel QWL terhadap kinerja dengan disiplin 
kerja serta kepuasan kerja sebagai variabel intervening pada tenaga kependidikan Fakultas Ekonomi UII. Data yang digunakan merupakan data primer hasil kuesioner yang disebarkan kepada 107 tenaga kependidikan tetapi yang berhasil kembali dan dapat diolah sebanyak 91 kuesioner. Metode analisis data yang digunakan dalam penelitian ini meliputi; uji validitas dan reliabilitas, uji asumsi klasik, regresi linier berganda, pengujian secara parsial dan analisis jalur.

\section{Hasil Uji Validitas dan Reliabilitas}

Pengujian validitas dilakukan berdasarkan analisis item dengan mengkorelasikan skor setiap item dengan skor variabel (hasil penjumlahan seluruh skor item pertanyaan). Teknik korelasinya memakai Pearson Correlation. Item pertanyaan dinyatakan valid apabila memiliki nilai signifikan dibawah 5\% $(0,05)$. Hasil uji validitas dalam penelitian ini tidak terdapat item pertanyaan yang mempunyai nilai signifikansi diatas 0,05 , sehingga item-item tersebut dinyatakan valid dan dapat digunakan dalam penelitian.

Pengujian reliabilitas dalam penelitian ini dengan menghitung besarnya nilai Cronbach's Alpha instrumen dari masing-masing dimensi variabel yang diuji. Apabila nilai Cronbach's Coefficient Alpha lebih besar dari 0.6, maka jawaban dari para responden pada kuesioner sebagai alat pengukur dinyatakan reliabel. Jika nilai Cronbach's Coefficien tAlpha lebih kecil 0,6, maka jawaban dari para responden pada kuesioner sebagai alat pengukur dinyatakan tidak reliabel. Hasil uji reliabilitas dapat dilihat pada Tabel 1.

Berdasarkan ringkasan hasil uji reliabilitas seperti yang terangkum dalam tabel 1 dapat diketahui bahwa nilai koefisien Cronbach Alpha pada masing-masing variabel nilainya lebih besar dari 0.6. Dengan demikian jawaban-jawaban responden dari variabelvariabel penelitian tersebut reliabel untuk digunakan sebagai instrumen penelitian.

\section{Uji Asumsi Klasik}

\section{Uji Normalitas}

Uji normalitas untuk mengetahui normalitas suatu distribusi data. Hasil uji normalitas dengan metode One-Sampel KolmogorovSmirnov Test menunjukkan angka signifikansi (probabilitas) sebesar 0,938 artinya seluruh variabel yang digunakan dalam penelitian memiliki random data yang berdistribusi normal karena nilai lebih besar dari 0,05.

\section{Uji Heterokedastisitas}

Model regresi yang baik tidak terjadi heterokedastisitas. Heteroskedastisitas muncul ketika terjadi varian dari distribusi probabilitas gangguan tidak konstan untuk seluruh pengamatan atas variabel penelitian. Untuk menguji heteroskedastisitas dalam penelitian ini menggunakan metode Spearmans rank correlations test. Jika nilai probabilitas (sig) > 0,05 maka dinyatakan tidak terjadi gejala Heterokedastisitas. Dalam penelitian ini semua variabel bebas mempunyai nilai probabilitas lebih besar dari taraf signifikan 0,05, maka dapat disimpulkan bahwa model regresi tersebut tidak terjadi Heterokedastisitas.

\section{Uji Multikolinieritas}

Uji multikolinieritas untuk mengetahui ada tidaknya korelasi antar variabel independen dalam sebuah model regresi berganda. Untuk mendeteksi ada tidaknya masalah multikolinieritas sebuah model regresi, dapat dilakukan dengan melihat nilai Variance Inflation Faktor (VIF) dimana nilai VIF harus di bawah nilai 10. Jika nilai Variance Inflation Faktor (VIF) hasil regresi lebih besar dari 10 maka dapat dipastikan ada multikolinieritas di antara variabel bebas tersebut. Dari hasil perhitungan menunjukan bahwa nilai VIF <10 untuk semua variabel independen (bebas). Hal ini berarti persamaan model regresi tidak mengandung masalah multikolinieritas atau tidak saling berkorelasi.

Tabel 1: Hasil Uji Reliabilitas

\begin{tabular}{lcc}
\hline Atribut & Cronbach's Alpha & Keterangan \\
\hline QWL $\left(\mathrm{X}_{1}\right)$ & 0,865 & Reliabel \\
Disiplin Kerja (X2) & 0,779 & Reliabel \\
Kepuasan kerja (X) & 0,799 & Reliabel \\
Kinerja (Y) & 0,787 & Reliabel \\
\hline
\end{tabular}


Tabel 2: Hasil Pengujian Hipotesis

\begin{tabular}{lllllll}
\hline \multicolumn{1}{c}{ Hipotesis } & \multicolumn{1}{c}{ B } & $\begin{array}{c}\text { Std. } \\
\text { Error }\end{array}$ & \multicolumn{1}{c}{ Beta } & \multicolumn{1}{c}{ T } & \multicolumn{1}{c}{ Sig. } & \multicolumn{1}{c}{ Keterangan } \\
\hline QWL $\rightarrow$ Kinerja & .739 & .115 & .564 & 6.444 & .000 & HO ditolak, Ha Diterima \\
QWL $\rightarrow$ Disiplin & -.223 & .123 & -.188 & -1.803 & .075 & HO Diterima, Ha Ditolak \\
QWL $\rightarrow$ Kepuasan & .677 & .086 & .640 & 7.853 & .000 & HO ditolak, Ha Diterima \\
Disiplin $\rightarrow$ Kinerja & -.208 & .115 & -.189 & -1.811 & .074 & HO Diterima, Ha Ditolak \\
Kepuasan $\rightarrow$ Kinerja & .905 & .090 & .731 & 10.107 & .000 & HO ditolak, Ha Diterima \\
\hline $\mathrm{R}=744^{\mathrm{a}}$ & & & & & \\
$\mathrm{R}$ Square 0.553 , F Hit $=35.900$ Sig $=0.000$ & & & & & Ho Ditolak, Ha Diterima \\
Adjusted Rsquare $=0.538$ & & & & \\
Standart error of the estimate $=0.5395$ & & & & \\
QWL, Disiplin \& Kepuasan $\rightarrow$ Kinerja &
\end{tabular}

\section{Pengujian Hipotesis}

Pengujian hipotesis satu sampai dengan hipotesis kelima (H1, H2, H3, H4 dan H5) dengan menggunakan uji $\mathrm{t}$ dan untuk hipotesis 6 dengan menggunakan uji $F$ seperti yang ditunjukkan pada tabel 2 .

$\mathrm{H}_{1}$ : QWL memiliki pengaruh signifikan terhadap kinerja pegawai.

Dengan menggunakan tingkat signifikan sebesar $\alpha=5 \%$ diperoleh nilai $\mathrm{t}_{\text {tabel }}$ pada $\mathrm{df}=\mathrm{n}-2$ $=91-2=89$ adalah 1,666 dan untuk nilai $t_{\text {hitung }}$ sebesar 6,444. Dengan demikian nilai signifikan $t_{\text {hitung }}$ lebih besar dari nilai $t_{\text {tabel }}$ atau ( $t_{\text {hitung }}$ $2,051>t_{\text {tabel }}$ 1,666), ini berarti bahwa QWL berpengaruh signifikan terhadap kinerja. Sehingga hipotesis pertama yang menyatakan ada pengaruh signifikan antara QWL terhadap kinerja pegawai terbukti atau diterima.

$\mathrm{H}_{2}$ : QWL memiliki pengaruh signifikan terhadap disiplin kerja.

Dengan menggunakan tingkat signifikan sebesar $\alpha=5 \%$ diperoleh nilai $t_{\text {tabel }}$ pada $\mathrm{df}=91-2$ $=89$ adalah 1,666 dan untuk nilai $t_{\text {hitung }}$ sebesar $-1,803$. Dengan demikian nilai signifikan $t_{\text {hitung }}$ lebih kecil dari nilai $t_{\text {tabel }}$ atau $(-1,803<1,666)$, maka dapat dinyatakan bahwa QWL tidak berpengaruh signifikan terhadap disiplin kerja. Sehingga hipotesis kedua yang menyatakan ada hubungan signifikan antara QWL terhadap disiplin kerja pegawai tidak terbukti atau ditolak.

$\mathrm{H}_{3}$ : QWL memiliki pengaruh signifikan terhadap kepuasan kerja.

Dengan menggunakan tingkat signifikan sebesar $\alpha=5 \%$ diperoleh nilai $\mathrm{t}_{\text {tabel }}$ pada $\mathrm{df}=\mathrm{n}$ $2=91-2=89$ adalah 1,666 dan untuk nilai $t_{\text {hitung }}$ sebesar 7,853. Dengan demikian nilai signifikan $t_{\text {hitung }}$ lebih besar dari nilai $t_{\text {tabel }}$ atau $(7,853>1,666)$, maka dapat dinyatakan bahwa QWLberpengaruh signifikan terhadap kepuasan. Sehingga hipotesis ketiga yang menyatakan ada hubungan signifikan antara QWL terhadap kepuasan pegawai terbukti atau diterima.

$\mathrm{H}_{4}$ : Disiplin kerja berpengaruh signifikan terhadap kinerja pegawai.

Dengan menggunakan tingkat signifikan sebesar $\alpha=5 \%$ diperoleh nilai $\mathrm{t}_{\text {tabel }}$ pada $\mathrm{df}=$ $\mathrm{n}-2=91-2=89$ adalah 1,666 dan untuk nilai $t_{\text {hitung }}$ sebesar $-1,1811$. Dengan demikian nilai signifikan $t_{\text {hitung }}$ lebih kecil dari nilai $t_{\text {tabel }}$ atau ($1,811>1,666)$, maka dapat dinyatakan bahwa disiplin kerja tidak berpengaruh signifikan terhadap kinerja. Sehingga hipotesis keempat yang menyatakan ada pengaruh signifikan antara disiplin kerja terhadap kinerja pegawai ditolak atau tidak terbukti.

$\mathrm{H}_{5}$ : Kepuasan kerja memiliki pengaruh signifikan terhadap kinerja individu.

Dengan menggunakan tingkat signifikan sebesar $\alpha=5 \%$ diperoleh nilai $\mathrm{t}_{\text {tabel }}$ pada $\mathrm{df}=$ $\mathrm{n}-2=91-2=89$ adalah 1,666 dan untuk nilai $\mathrm{t}_{\text {hitung }}$ sebesar 10.107 . Dengan demikian nilai signifikan $t_{\text {hitung }}$ lebih besar dari nilai $t_{\text {tabel }}$ atau $(10.107>1,666)$, maka dapat dinyatakan bahwa kepuasan berpengaruh signifikan terhadap kinerja. Sehingga hipotesis kelima yang menyatakan ada pengaruh signifikan antara kepuasan terhadap kinerja pegawai diterima atau terbukti.

$\mathrm{H}_{6}$ : QWL, disiplin kerja dan kepuasan kerja memiliki hubungan signifikan terhadap kinerja individu. 
Dengan menggunakan tingkat signifikan sebesar $\alpha=5 \%$ diperoleh nilai signifikan $\mathrm{F}_{\text {hitung }}$ sebesar 0,000. Dengan demikian nilai signifikan $\mathrm{F}_{\text {hitung }}$ lebih kecil dari nilai signifikan 0,05 atau $(0,000<0,05)$, maka dapat dinyatakan bahwa QWL, disiplin kerja dan kepuasan secara simultan berpengaruh signifikan terhadap motivasi. Sehingga hipotesis keenam yang menyatakan ada pengaruh signifikan antara QWL, disiplin kerja dan kepuasan kerja secara simultan terhadap kinerja pegawai terbukti atau diterima.

\section{Pengujian hipotesis 7 dan 8}

\section{Analisis Pengaruh Langsung dan Tidak Langsung}

Pengaruh variabel QWL terhadap kinerja pegawai sebesar $\mathrm{X}_{1} \rightarrow \mathrm{Y}=6,444$, Pengaruh variabel didiplin kerja terhadap kinerja pegawai $\mathrm{X}_{2} \rightarrow \mathrm{Y}=-1,811$, Pengaruh varibael kepuasan kerja terhadap kinerja pegawai $X_{3} \rightarrow Y=10,107$, Pengaruh variable $\mathrm{QWL}$ terhadap disiplin kerja $\mathrm{X}_{1} \rightarrow \mathrm{X}_{2}=-1,083$, Pengaruh variabel QWL terhadap kepuasan kerja $X_{1} \rightarrow X 3=7,853$, Pengaruh Tidak Langsung (Indirect Effect atau IE), Pengaruh variabel QWL terhadap kinerja melalui disiplin kerja, $X_{1} \rightarrow X_{2} \rightarrow Y=(6,444 x$ ($1,811)=-11,670$. Pengaruh variabel $\mathrm{QWL}$ terhadap kinerja melalui kepuasan kerja $X_{1} \rightarrow X_{3} \rightarrow Y=(6,444 \times 7,853)=50.605$

$\mathrm{H}_{7}$ : Diduga ada pengaruh tidak lansgung QWL terhadap kinerja melalui variabel disiplin lebih besar dari pada pengaruh langsung QWL terhadap kinerja.

Pengujian ke tujuh ini menganalisis pengaruh tidak langsung QWL terhadap kinerja melalui variabel disiplin kerja lebih besar daripada pengaruh langsung QWL terhadap kinerja. Pengaruh langsung variabel QWL terhadap kinerja sebesar 6.444. Sedangkan pengaruh tidak langsung QWL terhadap kinerja melalui disiplin kerja sebesar -11,670. Secara kuantitatif pengaruh tidak langsung memiliki poin yang lebih rendah daripada pengaruh langsung $(-11,670<6,444)$, sehingga hipotesis ke tujuh ditolak.

$\mathrm{H}_{8}$ : Diduga ada pengaruh tidak lansgung QWL terhadap kinerja melalui variabel kepuasan kerja lebih besar daripada pengaruh langsung QWL terhadap kinerja
Pengaruh langsung variabel QWL terhadap kinerja sebesar 6,444. Sedangkan pengaruh tidak langsung QWL terhadap kinerja melalui kepuasan kerja sebesar 50.605. Oleh karena itu hipotesis kedelapan diterima karena pengaruh tidak langsung QWL terhadap kinerja melalui variabel kepuasan kerja lebih besar daripada pengaruh langsung QWL terhadap kinerja melalui variable disiplin kerja $(50,605>6,444)$. Hal ini berarti pengaruh tidak lansgung QWL terhadap kinerja melalui variabel kepuasan kerja lebih besar daripada pengaruh langsung QWL terhadap kinerja bahwa jadi hipotesis ke delapan terbukti.

\section{PEMBAHASAN}

Dari hasil analisis dapat disimpulkan bahwa QWL, disiplin kerja, kepuasan secara bersamasama mempunyai pengaruh signifikan terhadap kinerja pegawai. Hasil yang ditemukan melalui perhitungan statistik berdasarkan analisis uji $\mathrm{F}$ dengan menggunakan tingkat signifikansi $\alpha=$ $5 \%$ diperoleh nilai signifikan $\mathrm{F}_{\text {hitung }}$ sebesar 0,000 . Dengan demikian nilai signifikan $F_{\text {hitung }}$ lebih kecil dari nilai signifikan 0,05 atau $(0,000$ $<0,05)$. Hal ini menjelaskan bahwa kinerja dari seorang pegawai akan baik atau buruk dipengaruhi oleh faktor QWL, disiplin kerja, kepuasan. Dengan mengetahui beberapa faktor tersebut, kinerja dari para pegawai tenaga kependidikan dapat nilai dan dievaluasi kesesuaiannya dengan melihat harapan dari organisasi dibandingkan dengan kinerja pegawai tenaga kependidikan. Dengan menggunakan evaluasi kinerja diharapkan sumber daya manusia yang dimiliki organisasi mampu memberikan kontribusi dan kinerja yang optimal dalam menyokong capaian tujuan organisasi. Setiap organisasi pasti sangat mempunyai kepentingan terhadap kinerja terbaik yang mampu dihasilkan dari rangkaian sistem yang ada dan berlaku dalam organisasi tersebut. Hal ini terjadi karena sumber daya manusia merupakan salah satu kunci dalam rangka mendapatkan kinerja organisasi terbaiknya.

QWL berpengaruh signifikan terhadap kinerja pegawai dibuktikan dengan hasil perhitungan uji $t$ dan nilai signifikan $t_{\text {hitung }}$ lebih besar dari nilai $t_{\text {tabel }}$ atau $(6,444>1,666)$. Ini berarti bahwa QWL membuktikan mampu memberikan kontribusi yang signifikan untuk meningkatkan kinerja pegawai tenaga kepen- 
didikan. Semakin baik QWL yang ada dalam organisasi akan menjadikan kinerja yang tinggi. Hal ini disebabkan karena adanya perbaikan iklim kerja yang mampu menjadikan dorongan besar bagi pegawai tenaga kependidikan dalam meningkatkan kinerjanya. Hal ini berarti membuktikan juga bahwa organisasi memperhatikan kepuasan dalam bekerja para pegawainya. Hasil dari penelitian sejalan dengan riset yang dilakukan oleh Bhe \& Che Rose (2007.) Dan didukung oleh hasil riset Lau (2000) yang menunjukkan bahwa kuatnya hubungan antar Quality of work life (QWL) dengan kinerja organisasi.

Dari hasil analisis penelitian untuk variabel QWL tidak memberikan pengaruh terhadap disiplin seorang pegawai dimana nilai signifikan $t_{\text {hitung }}$ lebih kecil dari nilai $t_{\text {tabel }}$ atau ($1,083>1,666)$. Hal ini menjelaskan bahwa QWL tidak berpengaruh kepada tenaga kependidikan untuk menjalankan kerja secara disiplin. Hal ini bertentangan dengan hasil riset terdahulu Nuryati (2010) dan juga penelitian Dunggio (2013) Disiplin kerja terjadi mungkin bisa dipengaruhi oleh banyak faktor antara lain budaya kerja dan kepemimpinan, motivasi dan lain sebagainya. Pada dasarnya banyak indikator yang mempengaruhi kedisiplinan karyawan suatu organisasi, diantaranya tujuan dan kemampuan, teladan pimpinan, balas jasa, keadilan, waskat, sanksi hukuman Hasibuan (2012). Dan disiplin akan berpengaruh terhadap kinerja jika dilaksanakan secara adil dan konsisten. Tetapi secara simultan disiplin berpengaruh terhadap kinerja pegawai.

Hasil penelitian membuktikan bahwa ada pengaruh positif dan signifikan dari variabel $Q W L$ terhadap kepuasan kerja karyawan. Hal ini dibuktikan nilai signifikansi thitung lebih besar dari nilai $t_{\text {tabel }}$ atau $(7,853>1,666)$. Senakin baik kondisi Quality of Work Life akan berdampak tingginya kepuasan karyawan dalam bekerja. Untuk itu perlu ditingkatkan program-program QWL yang ada di manajemen untuk menciptakan kepuasan para pegawai tenaga kependidikan. Selain manajemen meningkatkan program tersebut diperlukannya keterlibatan dan dukungan dari para pegawai dalam mencipakan QWL yang lebih baik. Program QWL harus dilakukan terus-menerus tidak hanya dilakukan dalam jangka pendek. Hal ini diperlukan untuk menciptakan motivasi kerja para pegawai. Salah satu program yang bisa dilakukan misalnya dengan melakukan pemberdayaan. Hal ini perlu dilakukan untuk menjadikan pegawai merasa dihargai dan mampu menumbuhkan kepercayaan diri dan aktualisasi diri.

Namun jika perusahaan tidak atau kurang memperhatikan QWL maka akan berpengaruh terhadap tingginya perputaran tenaga kerja. Sehingga organisasi sulit mendapatkan atau mempertahankan pekerja yang sesuai dengan kebutuhan perusahaan. Dan karyawan yang bertahan di organisasi akan sulit juga untuk bisa lebih berkinerja. Dan hal tersebut didukung oleh pendapat Umar (2001) perusahaan akan menghadapi kondisi perpindahan pekerja (labour turnovers) karena mereka lebih memilih untuk bekerja di tempat atau perusahaan lain yang menerapkan QWL yang lebih baik. Dan hasil penelitian ini sejalan dengan penelitian Fields \& Tachker (1992) yang menyatakan bahwa salah satu dimensi yang ada pada QWL ialah kepuasan kerja yang mempunyai signifikansi yang tinggi.

Pada pengujian disiplin kerja menunjukkan tidak ada pengaruh yang signifikan terhadap kinerja. Dibuktikan dengan nilai signifikan $\mathrm{t}$ hitung lebih kecil dari nilai $\mathrm{t}$ tabel atau ($1,811>1,666)$. Hasil penelitian ini bertentangan dengan penelitian Setiawan dan Waridin (2006), Susilaningsih (2008), Amran (2009), Zesbendri dan Aryanti (2009) menyatakan bahwa disiplin kerja berpengaruh secara parsial terhadap kinerja karyawan. Hal ini membuktikan bahwa tenaga kependidikan dalam menjalankan kerja untuk berkinerja tidak dipengaruhi oleh faktor disiplin. Karena disiplin akan benar-benar memainkan peran penting dalam membentuk tingkah laku dalam berkinerja jika dilaksanakan secara adil dan konsisten (Buhler, 2007). Akan tetapi dalam penelitian ini dengan menggunakan analisis secara simultan disiplin kerja berpengaruh; terhadap kinerja.

Dan kemudian pada pengaruh kepuasan terhadap kinerja menunjukkan pengaruh yang signifikan, dimana nilai signifikan $t$ hitung lebih besar dari nilai $t$ tabel atau $(10,107$ $>1,666$ ), sehingga makin tingginya kepuasan kerja karyawan akan menyebabkan makin tingginya kinerja karyawan. Kepuasan kerja merupakan salah satu komponen yang mendukung tercapainya produktivitas. Menurut Robbins \& Judge (2014), kepuasan kerja sebagai suatu sikap umum seseorang individu terhadap 
pekerjaannya. Dengan demikian, kepuasan kerja merupakan salah satu aspek yang penting di dalam praktek manajemen sumber daya manusia dan perilaku organisasi. Kepuasan kerja dapat mempengaruhi tingkat absensi, perputaran tenaga kerja, semangat kerja, keluhan-keluhan dan masalah-masalah personalia vital lainnya ( Handoko, 2008).

Kepuasan kerja yang tinggi sangat diharapkan karena hal itu berkaitan dengan hasil yang positif dan merupakan tanda organisasi yang dikelola dengan baik. Dan hasil penelitian ini sejalan dengan penelitian Robin dan Judge (2014) yang menyatakan bahwa kepuasan kerja sangat berhubungan dengan kinerja karyawan. Logikanya ialah pekerja yang bahagia ataupun puas merupakan pekerja yang produktif. Oleh karena itu kepuasan para karyawan perlu diperhatikan oleh para pimpinan, karena jika tidak akan berbahaya bagi organisasi. Selain itu berdasarkan pengujian melalui pengaruh tidak langsung QWL terhadap kinerja melalui didiplin kerja dan kepuasan kerja memiliki nilai yang rendah dibandingkan pengaruh langsung. Hal tersebut menandakan bahwa disiplin yang tinggi tidak berpengaruh terhadap kinerja. Hal ini terjadi karena kinerja sangat dipengaruhi oleh banyak faktor lain antara lain reward, komitmen karyawan dan lain sebagainya.

\section{KESIMPULAN}

Dari hasil penelitian ini membuktikan bahwa beberapa hipotesis yang diajukan terbukti. Namun ada dua hipetesis yang tidak terbukti yaitu pengaruh disiplin terhadap kinerja dan pengaruh QWL terhadap kinerja melalui disiplin kerja. Dalam penelitian ini menunjukkan pentingnya menciptakan QWL untuk menciptakan kinerja pegawai dengan kepuasan kerja sebagai variabel intervening. Meskipun disiplin kerja tidak berpengaruh terhadap kinerja secara parsial tetapi secara bersamasama juga ada pengaruh secara signifikan. Untuk itu perlu upaya yang dilakukan untuk meningkatkan QWL antara lain sebagai berikut dalam variabel QWL kategori pertumbuhan dan perkembangan kususnya dalam item pelatihan dan pengembangan perlu adanya tindak lanjut. Hal ini perlu dilakukan karena hasil riset menunjukkan bahwa organisasi belum secara maksimal memberikan pelatihan dan pengem- bangan tenaga kependidikan. Adapun bukti empiris menunjukkan bahwa QWL sangat berpengaruh terhadap kinerja. Dalam QWL item pelatihan dan pengembangan tenaga kependidikan untuk menghasilkan kinerja yang unggul diperlukan keterampilan yang sangat baik. Untuk itu perlu adanya Training Need Analysis (TNA) guna memenuhi kebutuhan tenaga kependidikan yang sesuai dengan kebutuhan pekerjaan. TNA digunakan sebagai dasar pelatihan dan pengembangan apa yang dibutuhkan seseorang sesuai dengan kebutuhan pekerjaan.

Dalam variabel QWL kategori kompensasi, untuk mengetahui apakah gaji yang diberikan sudah sesuai dengan beban kerja dalam suatu jabatan maka perlu dilakukan job evaluation sehingga dapat menilai posisi suatu jabatan dibandingkan dengan jabatan-jabatan yang ada. Selain dengan melakukan job evaluation perlu mengadakan salary survey terhadap perguruan tinggi yang dipilih secara sampling yang bertujuan untuk melakukan perbandingan data mengenai kebijakan, praktek dan metode penggajian. Nilai R Square sebesar 0,553 yang artinya variabel QWL, kepuasan kerja dan disiplin kerja mempengaruhi kinerja hanya sebesar 55,30 \% sedangkan 44,7\% dipengaruhi faktor lain. Maka perlu dilakukan riset lanjutan untuk mengetahui faktor yang berpengaruh terhadap kinerja selain faktor QWL, disiplin kerja dan kepuasan kerja.

\section{DAFTAR PUSTAKA}

Amran. 2009. Pengaruh Disiplin Kerja Terhadap Kinerja Pegawai Departemen Sosial Kabupaten Gorontalo. Jurnal Ichasan Gorontalo. Vol. 4, No. 2, Hal 2397-2413.

Balaji, R . 2014. A Study on Quality of Work Life among Employees, International Journal of Innovative Research in Science, Engineering and Technology, Vol. 2, Issue 2

Beh \& Rose. 2007. "Linking QWL and Job Performance": Implications for Organizations, Performance Improvement; 46, 6; Proquest pg.30.

Buhler, Patricia. 2007. Alpha Teach Yourself, Management Skills. Jakarta. Prenada Media Group 
Cascio, W. F.2006. Managing Human Resources: Productivity, Quality of WorkLife, Profit. $7^{\text {th }}$ Edition. USA . McGraw Hill Companies, Inc.

Daud. 2010. Investigating the Relationship between Quality of Work Life and Organizational Commitment amongst Employees in Malaysian Firms. International of Business and Management, Vol. 5. No. 10.

Dharma. 2012. Manajemen Kinerja Falsafah, Teori,dan Penerapanya. Yogyakarta. Penerbit Pustaka Pelajar.

Dunggio, M. 2013. Semangat dan Displin Kerja Terhadap Produktivtas Kerja Karyawan Pada PT. Jasa Raharja (Persero) Cabang Sulawesi Utara. Jurnal EMBA, Vol.1 No.4.

Fields, M and Tachker James. 1992. Influence of Quality of Worklife on Company and Union Comitmment. Journal academy of Management. Vol. 35.2.pg.439.

Ghozali, I.2005. Aplikasi Analisis Multivariat Dengan Program SPSS. Semarang. Badan Penerbit Undip.

Hani, Handoko T. 2008. Manajemen Personalia dan Sumber Daya Manusia. Yogyakarta. BPFE.

Hasibuan, MSP. 2012. Manajemen Sumber Daya Mausia. Edisi Revisi. Jakarta . Bumi Aksara.

Horst D.J., Broday E. E., Bondarick R., Serped L. F., Pilatti L. A .2014. Quality of Working Life and Productivity: An Overview of the Conceptual Framework, International Journal of Managerial Studies and Research (IJMSR).Volume 2. Issue 5. June 2014. PP 87-98.

Husnawati, A. 2006. Analisis Pengaruh Kualitas Kehidupan Kerja Terhadap Kinerja Karyawan Dengan Komitmen Dan Kepuasan Kerja Sebagai Intervening Variabel (Studi Pada PERUM Pegadaian Kanwil VI Semarang), Tesis Magister Manajemen (Tidak dipublikasikan), Semarang.
Program Pascasarjana Universitas Diponegoro

Lau, R.S.M. \& May, B.E. 1998. A Win-Win Paradigm for Quality of work Life and Business Performance. Human resource Development Quartely. Proquest Psychology Journals.Lewis, et al. 2001. Extrinsic and Intrinsic Determinants of Quality of Work Life. International Journal of health Care Quality Assurance Incorporating. Leadership in Health Service. Vol.14. p. 9-15

Mathis \& Jackson, J. 2006. Manajemen Sumber Daya Manusia. Edisi 10. Jakarta. Penerbit Salemba Empat.

Mousavi, S.H., Monfared S.Y., and Heidary A. .2011. Investigating the Relationship Between Life Quality And Productivity In Physical Education Office Employees In Zanjan Province. Procedia Social and Behavioral Sciences 15. 3665-3668.

Nuryati .2010. Analisis Kualitas Kehidupan Kerja Terhadap Produktivitas Karyawan di Eks-Karesidenan Surakarta (Studi Kasus pada Karyawan Bank Perkreditan Rakyat BPR di Eks -Karisidenan Surakarta). Probank. Vol. 18. No. 10.

Pramdhana, F.2013. Pengaruh Quality Of Work Life $(Q W L)$ Terhadap Kepuasan Kerja Karywan Pada. PT. Sumber Murni Lestari Makassar. Skripsi Sarjana (Tidak Dipublikasikan). Makassar . FEB Universitas Hasanuddin.

Pushpakumari, M.D.2008. The impact of job satisfaction on job performance: an empirical analysis. Journal of human resource, 6 (1): 89-105.

Rivai, Veithzal. \& Sagala, E.J. 2009. Manajemen Sumber Daya Manusia untuk Perusahaan. Jakarta. Rajagrafindo Persada.

Robbins, Stephen P. dan Timothy A. Judge. 2008. Perilaku Organisasi .Edisi ke12, Jakarta. Salemba Empat.

Setiyawan, Budi dan Waridin. 2006. Pengaruh Disiplin Kerja Karyawan Dan Budaya Organisasi Terhadap Kinerja Di Divisi 
Radiologi RSUP Dokter Kariadi Semarang. JRBI. Vol 2. No 2. Hal: 181-198.

Siagian, SP. 2009. Kiat Meningkatkan Produktivitas Kerja. Jakarta. Rineka Cipta

Siregar.2013. Metode Penelitian Kuantitatif: Dilengkapi Perbandingan Perhitungan Manual \& SPSS. Edisi Pertama. Penerbit Kencana Prenada Media Group. Jakarta.

Sugiyono.2012. Metode Penelitian Kuantitatif Kualitatif dan $R \& D$, Bandung. Alfabeta.

Sumbodo, D. P. 2010. Daya Saing dan Produktivitas Indonesia dan Negara ASEAN.[online]. Diakses pada tanggal 19 Januari 2014 dari http://didiksumbodo.com/2010/02/daya -saing-dan-produktivitasindonesia.html
Susilaningsih, Nur . 2008. Pengaruh Kepemimpinan, Disiplin, Motivasi, Pengawasan Dan Lingkungan Kerja Terhadap Kinerja Pegawai (Studi Pada Badan Perencanaan Pembangunan Daerah Kabupaten Wonogiri). Excellent. Vol. 1 No. 2, Hal. 1-19. Taleghani M, Chegin M.G., Hashemi M.H.2014. An Overview of the Quality of Working Life and its Importance and its Impact on the Organizational Commitment. Universal Journal of Management and Social Science. Vol. 4. No.2.

Zesbendri, Anik Aryanti. 2009. Pengaruh Disiplin Kerja Terhadap Kinerja Pegawai Pada Kantor Pusat Statistik Kabupaten Bogor. Jurnal Manajemen STIEVol.4, No.3, Hal. 11 -19. 